\title{
The military and democracy in Thailand
}

\section{Abstract for chapter 3}

\section{Author: Suchit Bunbongkarn}

In discussing the role of the military in the democratisation process in Thailand, the author poses the questions: what role does the military have to play in the process of democratisation, and under what circumstances will its political role change?

In answer to these questions, the author addresses the following areas: coups and the military's struggle for state power; coups and democratisation; the military's mission and it's political involvement; the Communist insurgency and military-initiated liberalisation; the military, society and democratisation; and the May 1992 uprising and the prospect of democratic development.

In conclusion, the author states that democratic reforms should be carried out gradually and that the military should learn how to tolerate the democratic processes, and play the game by the rules.

Keywords

authoritarian rule, coups. democracy, military 


\section{3}

\section{THE MILITARY AND DEMOCRACY IN THAILAND}

\section{Suchit Bunbongkarn}

A stable democracy requires public commitment to democratic norms and procedures, a strong and institutionalised party system, and active pressure groups. Such conditions have yet to be fully developed in Thailand. Since the ending of absolute monarchical rule in 1932, the fragility of representative institutions and public political apathy have allowed the military to take control of state power. Over the past sixty years the struggle for power between men in uniform and civilian politicians has been reflected in a series of coups and continued military control of the state. The armed forces have been concerned not only with national defence but with other dimensions of national security such as political stability. Through effective control over state apparatuses, particularly the police force and civil service, the military has dominated political decision-making; the course of political change has not been set by civilian politicians or political parties. The party system is far from institutionalised and its lack of mass support is clearly evident. As a result, the separation between democracy and military rule remains fragile in Thailand.

In the last ten years, however, Thailand has undergone dramatic changes which perhaps have provided the preconditions for democracy: pluralism, open politics, and rapid industrialisation. These developments have not put an end to authoritarian rule. A coup occurred in February 1991. The military subsequently appointed a civilian government, but pro-democracy forces have become very active in campaigning against the pro-military constitution and General Suchinda Kraprayoon's assumption of the premiership. Thus, although the military continues to play an important role in politics, it faces increasing competition for state power from civilian politicians. It is being forced to tolerate the increasing strength of representative institutions and extra-bureaucratic forces and to adjust its role accordingly. A 'guardian' role continues to be advocated by the military, but that role is unlikely to enjoy as much public support as in the past. In 
discussing the role of the military in the democratisation process in Thailand, the interesting questions therefore are: what role does the military have to play in the process of democratisation, and under what circumstances will its political role change?

\section{Coups and the Military's Struggles for State Power}

In Thailand, coups, not elections, have become the norm for change of political leadership and government (Bunbongkarn 1987a:42-52). Since 1932, political change has evolved in a cyclical pattern - starting with a coup, followed by an election and a short period of open politics, before a crisis leading to another coup. In most cases, the coups provide a channel for the Royal Thai Army (RTA) to exert influence on the political situation, and have little to do with political transformation. They reflect struggles for power among the top military officers and civil servants among the political class. Some coups have been launched to oust civilian governments; others have been the result of competition for state power between factions within the military establishment. Rarely have political norms and practices been altered.

The first coup in modern Thai political history, which took place in 1932, can be considered one of the very few military interventions which led to a regime change, since it overthrew the absolute monarchy and replaced it with a form of constitutional rule. Although a democratic government was not installed, some democratic norms and practices were introduced. Subsequent military interventions were staged simply to provide opportunities for military leaders to acquire senior political positions. The 1947 coup was a case in point. It provided an avenue to power for a new group of army officers who were not previously involved in politics (Samudavanija and Bunbongkarn 1985:83). These officers were much more traditionalist than the 1932 coup leaders. Most of them did not have the same degree of exposure to Western education and culture and they lacked political vision and a blueprint for political development. Apart from personal ambition, the motive behind the coup was to return to military rule and restore the prestige of the armed forces. At the end of World War II, the armed forces were in disarray as the government was under Allied pressure to demobilise the army which had cooperated with Japanese troops in military operations during the war. The army was humiliated and the civilian-led, anti-Japanese underground Free-Thai Movement was the hero.

After the 1947 coup, the armed forces split into factions, each competing for power. But although the military elite was divided by personal interest, the military's political dominance remained unaffected. The group supporting 
democracy was small and confined to elected parliamentarians and some intellectuals. In the 1950s, the Thai public was politically apathetic and viewed politics as a matter for the ruling class. Political parties were unorganised and lacked mass support; they did not present a threat to the military.

Military rule in Thailand was further strengthened when Marshal Sarit staged a coup in 1958 (Chaleamtiarana 1979). The distinctive characteristic of this coup was the combination of conservatism and capitalism. Sarit, who had been a key member of the 1947 coup group, rose rapidly to power after this coup. He later came into conflict with senior leaders, particularly Field Marshals Pibul and Phin and Police General Phao. Sarit launched a coup to oust those three from power in 1957. A second coup the following year, however, dealt a heavy blow to all liberal and progressive elements as well as to the representative institutions. Sarit soon realised that political instability in part derived from the fact that the armed forces lacked cohesiveness. An ideology was needed to reunify the armed forces and to guide the direction of political change. Sarit's response was a conservatism which raised the prestige of the monarchy, consolidated bureaucratic rule, abolished constitutionalism, and limited political activities.

Most analysts agree that Sarit's military rule was detrimental to democratic development, as democratic institutions and practices were not given a chance to survive. Sarit believed that what the country needed most was not political but economic development. Nevertheless his emphasis on economic development eventually strengthened the business community and other extra-bureaucratic forces, which in turn contributed to the strength of civil society. An influx of foreign investment, more systematic national economic development plans, and the expansion of economic infrastructure strengthened the business sector. The student organisation which led the historic uprising in October 1973 gained strength from the expansion of higher education initiated during Sarit's period.

\section{Coups and Democratisation}

The coup in 1977 was different. While other coups were staged to enhance military rule, this intervention was intended to allow greater democratisation, with the promulgation of a democratic constitution, elections to a House of Representatives, and the granting of political freedoms. The coup occurred a year after the military had seized power from the civilian government in a volatile political situation created by a series of clashes between left- and right-wing groups. The civilian government emerged from an uprising in 1973 which overthrew military rule, but the government could not cope with the political violence and internal 
bickering in the government parties, which characterised open politics. The seizure of power by the military in 1976 terminated the three-year period of the civilian regime and installed an ultra-rightist civilian government under the supervision of a military junta. The new government lasted only one year before being ousted by the same group of military leaders who had installed it.

One of the major reasons for the military staging the 1977 coup was the political suppression practised by the government. Most liberal and progressive groups were labelled communists or communist sympathisers and severely suppressed. A number had to flee to the jungles, where they joined the Communist Party of Thailand. Military leaders came under pressure from various groups in the civil society, and from a powerful faction in the army which could not tolerate this ultra-rightist policy, to replace the government with a more liberal one.

Following the 1977 coup parliamentary rule lasted almost twelve years, the longest period of civilian rule since 1932 (though the government survived two attempted coups). Political parties gained strength and legitimacy. Commitment to democracy among the educated Thai was on the rise and the military seemed close to accepting democratic norms and practices (Boonprasert 1990).

In February 1991, however, the military staged another coup, putting an end to parliamentary rule. Like the coups in 1947 and 1976, the military justified the intervention in terms of the weakness of the civilian government. It also cited the excessive corruption of civilian politicians, which had clearly undermined the legitimacy of the government. But the real reason behind the coup was the mutual distrust between the military and the government. A number of leading military officers felt insecure when Prime Minister Chatichai appointed ex-army chief General Arthit Kamlangek as deputy Defense minister in early 1991 to tighten control over the armed forces (Bunbongkarn 1992:132-33).

Prime Minister Chatichai came to power in 1989 after General Prem declined an invitation to continue in the premiership. As the leader of the biggest party in the National Assembly after the 1989 general election, Chatichai was the only legitimate successor to General Prem. He had maintained good relations with the military until the second year of his term, but his intention to exert more control over the military caused concern in the armed forces.

After the coup, the military was faced with a problem of how to deal with the growing democratic forces. Protests led by pro-democracy parties, student organisations, and other civic groups against the draft constitution signified the growing commitment to democracy within those groups and forced the coup leaders to grant concessions (such as agreeing not to let active military officers hold political posts). 


\section{The Military's Mission and Its Political Involvement}

To hold on to power, the military had to adjust its mission and organisation to changes in political and social circumstances. Before 1932 the armed forces' mission was to safeguard the king and defend the country from outside aggression. After the People's Party overthrew the absolute monarchy the military's mission was changed to that of protecting the new constitution and the new regime. The military's guardianship mission expanded for the first time into political affairs. It became a key instrument of support for politicians in uniform.

Between 1932 and the end of World War II the armed forces expanded and developed not only to meet the government's defence needs but also to strengthen the support for Field Marshal Pibulsongkram, who emerged rapidly after the 1932 coup as a strong political leader. After the war a communist threat provided the armed forces with a new justification for its expansion and involvement in national affairs. The victory of the Chinese Communist Party in 1949, the outbreak of the Korean War in 1950, and the Vietminh's struggle for Vietnam's independence in the early 1950s forced Thailand to ally itself with the US. Postwar Thai militarism grew to meet the challenge of communism and Thailand was integrated into the US collective security system. The Thai armed forces were modernised and expanded further with the assistance of the US. Between 1950 and 1971 US military assistance averaged \$US46 million per year, which represented 50 per cent of the Thai Defence Ministry's total budget (Snitwongse 1990:91). As a result US influence was pervasive in the Thai military, especially in education, training programs, strategic thinking and military hardware.

One aspect of US influence in the 1950s was the perception of the communist threat. The Thai military shared the US view that the communist threat would come in the form of overt aggression from outside. The domino theory and John Foster Dulles's containment policy received much attention within the government and the military establishment. As a result, the development of the armed forces was geared to the threat of conventional warfare.

The development of the armed forces further strengthened the political position of the military elite. During the 1950s and 1960s civilian political forces were unorganised, fragile and unable to challenge the military. They lacked mass support and linkages to groups in the society. The Democrat Party was the only organised political force but it was popular only in Bangkok. The military establishment was expanded in part to provide a basis of support for military leaders. Since coups had become a method of changing government, the military organisation was an important political resource for those officers who sought to use the coup as an avenue of control over state power. 
Among the three armed forces, the army enjoyed the strongest growth. The navy, which had been powerful before World War II, suffered from its abortive coup in 1951. The air force had always been a close ally of the army and supported the army in becoming the leading service. It is not surprising, therefore, that army leaders have acquired more political posts than the other services.

US military assistance did not affect the political attitudes and thinking of Thai military officers. US assistance up to the 1970s included training programs for Thai officers at major military educational institutions like West Point and Fort Leavenworth, and American advisers were sent to Thailand to organise training programs for military personnel. But these programs did not result in transformation of the political outlook of Thai military officers. Liberal-democratic attitudes, military professionalism, and the concept of civilian supremacy did not emerge within the military establishment. American assistance coincided with an increase in the military elite's involvement in political affairs and, perhaps because the US made no effort to dissuade them from political involvement, the political outlook of the military elite remained the same.

Without challenge from the democratic forces it is impossible to see the military furthering the development of democracy in Thailand. The modernisation and strengthening of the armed forces has led only to an increase in the political power of the military elite, strengthening their advantage in the struggle for state power. For three decades after World War II, the armed forces were split and became the personal power base of military leaders. Sarit, Thanom and Prapas, who first came into politics through the 1947 coup and reached the peak of their power in the 1960s, were known to have used the armed forces as their support base. Political parties like the National Socialist Party of Sarit and the United Thai People of Thanom and Prapas did not have political significance and were used as a façade to give their regimes the appearance of legitimacy. Personalisation of politics bred factionalism within the armed forces.

\section{The Communist Insurgency and Military-Initiated Liberalisation}

The military's failure to suppress the communist insurgency is one of several important factors which contributed to the military-initiated liberalisation which brought a relatively long period of parliamentary rule in the 1980s. Thai military leaders were concerned with the communist insurgency from the early 1960s. But they believed that it was external in origin and consequently that the success of the insurgency depended in large part on the communist movement's success in Vietnam and Laos. To counter the insurgency in Thailand, the RTA saw improvement of the people's livelihood in the affected remote rural areas as essen- 
tial. Political solutions to the problem were not considered (Snitwongse 1990: 93-94).

Marshal Sarit's action reflected the military elite's perception of that period. Communist suspects were severely punished. The military launched rural development projects in peripheral areas where the state was not in evidence. The military believed that the communist insurgents were merely bandits, without an organisation, and could be easily dealt with by the police force. In 1965 when overt armed insurgency broke out in the northeast, armed suppression was carried out on the assumption that military means were the only way to wipe out the communist movement. This response only fuelled the insurgency which expanded rapidly in other parts of the country in the late 1960s. Military campaigns against the communists intensified in the 1970s, but further encouraged the spread of the armed struggle. Civic actions were carried out against poverty and hardship in peripheral areas, but these did not stop the expansion of the insurgency.

After 1977, when General Kriangsak staged a coup which overthrew the rightist regime of Thanin Kraivixien, a new strategy of counter-insurgency was initiated to replace military campaigns. Intensification of the insurgency in response to the sweeping suppression of liberal and leftist movements during the twelve months of Thanin's rule became a major concern to the military. In addition, an exodus of more than a thousand students, intellectuals and laborers to join the Communist Party of Thailand, following the ruthless suppression of the student protest on 6 October 1976, expanded its support base and convinced the military that a new counter-insurgency policy was needed.

The military-initiated liberalisation began in 1978 when Kriangsak's government lifted the suppression order on the CPT and its sympathisers and enacted an amnesty law for those who joined the CPT after the 1976 coup. As a result, defectors, many former student leaders and intellectuals, left the Communist Party and resumed their normal lives. The political offensive strategy became official when the government of General Prem Tinasulanond issued Prime Ministerial Order No. 66/2523. This detailed a counter-insurgency policy which stressed the priority of political means over military actions to suppress the CPT. It laid down operational guidelines, such as the elimination of social and economic injustices, promotion of political participation, promotion of democratic institutions and movements, and assurance of political freedom. In short, the order made it clear that building full democracy was the only means to defeat communism.

Attempts were made to implement the order. Several mass organisations were established in rural areas to mobilise the people in support of the government's 
insurgency suppression program. The military claimed that these organisations were evidence of democratic development at the grassroots level since the people were encouraged to participate in the administration and the development of their villages. The Thai National Defense Volunteers, Volunteer Development and SelfDefense villages, and the Military Reservist for National Security organisation were set up as centres for mobilisation and training of villagers for democratic participation (Bunbongkarn 1987b:53-58).

It is difficult, however, to see these projects as catalysts to democratisation in Thailand when the administrative structure at the village and tambol (sub-district) levels remained unchanged. Although the village headman and tambol officer (kamnan) were elected by the people, they came under the authority of the provincial administration, and the village and tambol administrations were parts of the provincial administration and received their budgets from the central government. The people were not given the authority to decide the future of their community and the local administrative structure and the principle of development from above remained unaffected.

\section{The Military, Society, and Democratisation}

More important, however, was the liberalisation and democratisation at the national level. After the 1977 coup, Prime Minister Kriangsak promised to promulgate a permanent constitution within a year and hold a general election a few months later. Pressure for liberalisation came from a group of middle-ranking officers, known as 'The Thai Young Turks', which was formed within the army after the October 1973 uprising. Their demand for democratic reform was less ideological than pragmatic: they favoured strong leadership and coups, but liberalisation and democratisation were acceptable if they could resolve national conflict and promote political stability.

The twelve years of liberalisation and parliamentary rule after 1979 would not have been possible without the initiative of the Kriangsak government. Despite liberalisation Thailand still faced instability, partly because the military continued to maintain strong political influence throughout that period. The military regime initiated liberalisation because it wanted to ease the political tension which had resulted from the rightist policies of the Thanin government. But assurance had to be given to the military that its corporate interests would not be endangered. Open politics in this period allowed representative institutions to develop and gradually made inroads on the military-dominated regime. Coups staged in 1981 and 1985 showed that the military was disturbed by the decline of the bureaucratic polity and the development of political 
parties. The army's attempt in 1983 to have the constitution amended to allow serving military officers and civil servants to hold cabinet portfolios was further evidence of this. (The 1978 constitution permitted active government and military officers to assume political posts for four years only after the 1979 general election.)

Prime Minister Prem, who took the helm of the country from 1981 to 1989, had to maintain a delicate balance. It was a period during which liberalisation and democratisation were put to the test. Although the military's power was waning, it was still powerful and was a major force in the state. But as civil society was becoming more influential, the army had to review its role in the political arena. While factions like the Young Turks accepted coups as a strategy, others believed that they had to play the game by the rules. They agreed that since the Thai political system was in a transitional phase, the military could not withdraw itself from the political scene; it had to take part in politics to make democratisation possible. The army's role as political broker and supporter of the Prem government was emphasised. Nevertheless the military was not willing to let political parties take full control of the state. Army leaders were involved in forming the government in order to make sure that the prime minister and other key cabinet members were on their side. Political parties were not allowed to interfere in matters of the military's domain such as the defence budget, counterinsurgency operations, personnel reshuffles, and control of the electronic media. Stability during this liberalisation period, though delicate, was maintained because the boundary between the military and civilian politicians was observed by both sides.

The breakdown of the democratisation process in 1991 and the pro-democracy protests against Prime Minister General Suchinda Kraprayoon in mid May 1992 showed that although the military was able to seize state power, as it did in the February 1991 coup, civil society was strong enough to curb the military's influence in government. The 1991 military intervention reflected the armed forces' disaffection with the increasing influence of political parties and the civil society's attempt to exert more control over the military. It did not meet resistance because the Chatichai government had lost the support of the people. Nevertheless, when General Suchinda resigned from the army and assumed the premiership after the April 1992 election the civil society was able to force the former army chief to step down. Opposition parties and other pro-democracy groups launched a protest with the support of the urban middle class, including businessmen, intellectuals, and people from various professions. It was the biggest protest witnessed in Thailand since the student uprising in 1973. The demands of the pro-democracy groups were strengthened by the ruthless suppression of 
the demonstration by the military, which led to stronger public condemnation.

One of the problems of democratisation in Thailand has been that, because of a long period of bureaucratic and military domination, a democratic regime often has difficulty establishing legitimacy in relation to the traditional political culture. Economic and social changes in recent years have produced a new urban, educated middle class which subscribes to the principles of democracy; but the possibility of an effective democratic government could hardly be expected. The Chatichai government (1989-1991) gained legitimacy because it was popularly elected, but it later lost legitimacy because it could not tackle effectively the corruption in the government. Anand's government, which succeeded it after the 1991 coup, assumed power without legitimacy because it was appointed by the military junta. But it went on to gain public recognition as one of the most reliable, transparent and efficient governments. The fact that all democratic regimes in Thailand have been weak and inefficient has affected their legitimacy. And if they cannot improve their performance and accountability, their popular support will be easily undermined.

With this in mind, the military has generally preferred a non-partisan prime minister, and has given him full support in order to ensure the government's stability. This implies a preference, on the part of the army, for effectiveness over legitimacy. After the 1992 general election the military wanted to continue its control of the state and to insulate the state mechanisms from popular forces. What the military leaders did not anticipate was the strength of the civil society. Attempting to force the political parties and the people to accept Suchinda as the government leader was a big mistake. It reflected the inability of the military elite to understand the development of societal groups which were determined to fight for democratisation and a weakening of the political power of the military.

\section{The May 1992 Uprising and the Prospect of Democratic Development}

The downfall of General Suchinda has again raised one of the important questions which arises whenever there is a breakdown of authoritarian rule: is Thailand going to have a stable and long-lasting democracy? The answer is probably no. It is difficult to anticipate sustained democratisation. One reason is that changes have yet to take place in the military establishment to make it more conducive to democratic development. The concept of civilian control is still unacceptable within the armed forces. More important, the military continues to insist on its political guardian role, which implies a right to intervene whenever it feels that national security is threatened. During the 1980s there were signs that the army was about to accept a civilian-dominated regime, but as one expert on Thai 
security affairs said, the change in the military's political thinking was 'in a very formative stage, incoherent and inconsistent' (Snitwongse 1990:103). Thus, when the Class 5 Group (the fifth graduating class from the Military Academy under the West Point curriculum) assumed leadership in the RTA, liberal attitudes in the army began to erode. Class 5 officers led by Suchinda and Issarapong Noonpakdi, the former army chief, are not known for their liberal political ideas. The group was first formed to counter the Young Turks group, but later transformed itself into a powerful pressure group to work for the benefit and promotion of its members. The group has firm control of the army and has not been much affected by the pro-democracy protest and the downfall of Suchinda.

Having been resurrected, Thai civil society now poses a real threat to the military. The business community is expanding and becoming more complex. Several professional and societal groups, including doctors, lawyers and teachers' associations, are demanding an end to the military's political involvement. It can be argued that these popular uprisings have been largely a phenomenon of Bangkok and other major urban areas, and that they are unlikely to have a strong impact in the country. However, it has always been the urban people who have led public opinion and successfully pressed for political reforms. The May 1992 uprising was a product of the politicisation of urban groups. Now that authoritarian rule is fading, the question of whether democratisation will be consolidated remains to be answered. The military establishment is still unified and reform from within cannot be expected in the immediate future. In the long run, if the politicisation of societal groups continues, military reform will become inevitable, and as a result political democracy will be given more chance to consolidate itself.

The triumph in the September 1992 election of the pro-democracy forces comprising Chuan's Democratic Party, the New Aspiration Party (NAP), the Palang Dham Party and Solidarity - and the subsequent establishment of the democratic government led by Chuan, marked another important development in civil-military relations. The armed forces have pledged to support the government and to remain in their barracks. The military leaders once again have reiterated that the military will not interfere in political affairs; modernisation programs and professional development will be their main priorities. Chuan also recognises that civil-military relations are a delicate matter and civilian control can hardly be achieved if the prime minister and defence minister are unacceptable to the armed forces.

To placate the military, Chuan appointed a retired and respected general to head the Defense ministry. In addition, he has been very cautious in dealing with technical matters such as national security policy, strategic issues, defence budgets, and military personnel appointments, in the hope that the relationship 
is not jeopardised. Despite these efforts, however, the relationship continues to be delicate and a lot needs to be done to strengthen it.

Among other things, the civilian government must improve its efficiency, accountability and stability. The Thai political experience suggests that the fragility of democratic governments encourages military intervention. To change the military mind-set into a more democratic one, the civilian democratic government must prove itself strong and responsible.

Democratic reforms should be carried out gradually. The military and other conservative elements are not in favour of radical changes. The vote by the military-dominated Senate in March 1994 against the government parties' bill to reduce the number of the senators showed that the military, though supporting the government, would not let the democratisation process go too far or too fast. The pro-democracy groups which advocate more drastic reform should keep in mind that the military and the conservatives are still influential and control a variety of political resources. Even the urban middle class, which supported the pro-democracy groups during the May 1992 event, does not agree with radical political reform. The politics of compromise is likely to be essential during the initial stage of democratisation.

Democratisation involves institutionalisation of the competitive process by which the people elect their leaders. This can be done by allowing continuity of the representative government and elections. The military should learn how to tolerate the democratic processes and play the game by the rules. The more elections Thailand has, the more developed the competitive process will be. Once the process is institutionalised, coups will find no place in the Thai political system. 